\title{
VAGUENESS AND DISSOCIATION IN ENGLISH POLITICAL NEWS DISCOURSE
}

\begin{abstract}
The main goal of this paper is to indicate the importance of the issues of vagueness and dissociation in discourse interpretation. The discourse that is taken into consideration is the discourse of political news written in the English language. This particular discourse is widely available to readers and deals with important political issues, which is why the choice of words and phrases should ideally be unbiased and accurate. If not, the readers may misinterpret the discourse and have a wrong impression of the political issue. In this research, newspaper articles are taken as an example of political news discourse. All articles analyzed were written in online British and American broadsheet and tabloid newspapers and they all dealt with the migrant crisis and 2019 Hong Kong protests. By taking into consideration the political context and the theoretical framework used in this research, 44 instances considered to be examples of vagueness and dissociation were identified, which were found in 14 newspaper articles.
\end{abstract}

Key words: dissociation, vagueness, broadsheet newspapers, tabloid newspapers, political discourse, pragma-dialectics

\section{Introduction}

Newspapers are daily read by people around the world wanting to know the latest news and trends. Considering their availability and big readership, newspapers can also be conveniently used to spread propaganda. Additionally, they can be used as an instrument for swaying public opinion by presenting biased information and by supporting a certain world view. Consequently, readers become engulfed with articles and reports that can easily affect their understanding of events and situations.

Where this can be most apparent is the discourse of political news. Generally, in politics and political news discourse, a difference of opinion is expected, which means all parties are ready to present their standpoint as the only acceptable one. However, this also means that interlocutors can test the acceptability of standpoints if they do not agree with what was advanced.

Therefore, misunderstandings and misinterpretations are a common occurrence because judgements may vary. Specifically, the use of vague, ambiguous,

\footnotetext{
${ }^{1}$ Received April 2021 / Accepted May 2021

2 e-mail: katarinad0404@gmail.com
} 
indeterminate or dissociative meanings of words can be regarded as a good example of the confusion and disagreement that arise from different interpretations and conceptualizations of words.

This paper investigates broadsheet and tabloid newspaper articles that reported on two political topics - the migrant crisis and the 2019 Hong Kong protests, in order to detect the differences and similarities in the use of vocabulary between the formats.

The following chapter is called Language Use Rule and it is focused on the most important notions regarding this rule; the next chapter is Strategic Maneuvering and it explains how parties can deliberately affect other parties' opinion and viewpoint on an issue; the next two chapters are called Vagueness and Dissociation, which give definitions and interpretations of these two notions; the following chapter is called Tabloids versus Broadsheets and it compares and contrasts the two newspaper formats. The next chapter is called Methodological Framework, followed by Research results and Discussion and finally, the Conclusion.

\section{Language use rule}

The rule that this paper is particularly interested in is the Language Use Rule (van Eemeren, 2018, p. 61). The Language Use Rule is the tenth rule belonging to a set of rules that regulate and describe the conduct of argumentative discourse in all four stages of a critical discussion. More precisely, van Eemeren (2018, p. 61) states that this rule is focused on preventing misunderstandings that may result from both "non-transparent, ambiguous, vague or equivocal formulations" and "inaccurate, sloppy or biased interpretations". Van Eemeren and Grootendorst (2004, pp. 195-6) imply that the most important thing is that discussants should not use any "partly clear or confusingly ambiguous formulations" and that they should not misinterpret the other party's formulations on purpose. In other words, all participants in the discussion need to strive to express their intentions and to interpret the other participants' intentions as accurately as possible if they want to resolve their difference of opinion. If not, they add, inaccurate formulations and problems with interpretation may lead to the creation of a "pseudo-difference" in the confrontation stage or "pseudo-solution" in the concluding stage. Still, absolute clarity is impossible and problems of formulation and interpretation are not linked to any particular discussion stage but may appear in all stages of a critical discussion.

A discussant is guilty of the violation of Rule 10, or the fallacy of unclearness, if he/she makes use of certain unclearness in their wording to improve their own position in the discussion. Unclearness can occur in various forms. As van Eemeren and Grootendorst (2016, pp. 197-8) note, the violation may result from structuring unclearness at the textual level, or from the obscure structure, "illogical" order, lack of coherence and so on. Unclearness can also emerge at the sentence level, during the performance of speech acts. However, this does not lead to any problems of interpretation, but sometimes the context and situation will leave too many possibilities open and the function of the implicit speech act will be obscured. 


\section{Strategic maneuvering}

Van Eemeren explains (2010, p. 41) the concept of strategic maneuvering. According to him, strategic maneuvering refers to efforts performed in argumentative discourse in order to keep the balance between reasonableness and effectiveness. The term maneuver, in this case, means moving toward the best position in view of the argumentative circumstances; the term strategic means that the goal aimed for in the maneuvering has to be reached by clever and skillful planning. They distinguish three aspects of strategic maneuvering, which are all associated with distinct types of choices that are made in the maneuvering. According to van Eemeren (2010, pp. 93-4), the choices are:

1. The choice from the available "topical potential." Topical potential is a name for the range of options available for making an argumentative move;

2. The choice of how to adapt the argumentative move to satisfy "audience demand." Parties which strategically maneuver may be expected to choose what pleases the audience;

3. The choice of how to use "presentational devices," or a choice as to how the argumentative moves are to be presented in a way that is strategically best. Arguers who strategically maneuver will choose the communicative means they reckon to have the most beneficial effect.

The expression "audience demand" (van Eemeren, 2010, pp. 108-10) refers to the requirements that must be fulfilled in the strategic maneuvering in order to achieve a rapport with the people the argumentative discourse is aimed at. If a party wants to be both reasonable and effective, the strategic moves the party makes must connect well with the views and preferences of the people they are directed at. The argumentation can be directed at the persons that are his immediate addressees, but it may also have an effect on many others. In the first case, the antagonist is called the "official" antagonist and $\mathrm{s} / \mathrm{he}$ is reached directly and intentionally. In the second case, the antagonist is called the "third" party and can be reached intentionally or unintentionally but s/he can also judge the acceptability of the argumentative moves. This party can be constituted of people who are, for example, a regular audience, accidental listeners, television viewers watching a speech that is directed to a different public, etc. When it is apparent which audience the arguer considers the more important to reach, they are given the name the "primary audience"; on the other hand, the person or persons instrumental in reaching them are the "secondary audience."

\section{Vagueness}

In philosophy, Williamson notes (2001, p. 61), vagueness is used as a name for the phenomenon of borderline cases. This means that an expression or a concept is vague if and only if it has borderline cases, that is, cases in which it neither 
clearly applies nor clearly fails to apply. Using an example that Williamson gives, a borderline case for the term "tall" would be a person who is neither clearly "tall" nor clearly "not tall." The application of the term may vary among speakers. Therefore, someone may apply the term "tall" to a person, whereas someone else may not, even with the same view of the person.

According to Fenstad (2011, p. 696), vagueness is an "important source of indeterminateness in language use". The most important question is whether an entity falls under a concept or not, as it mostly deals with the meaning of lexical items. Van Eemeren and Grootendorst (2016, p. 200) give the following example of vagueness: one discussant called a person a kleptomaniac as soon as they had stolen one thing, whereas the other discussant only found the term appropriate when the person was guilty of persistent theft. Both agreed that theft was involved, but the question is how often it must take place. This form of vagueness is called linear because it is caused by possible differences in the degree to which something or someone has to fulfill a criterion before a description becomes applicable. Examples of linearly vague words are the terms such as "bald", "rich", etc.

Another form of vagueness that van Eemeren and Grootendorst (2016, p. 201) give has to do with family resemblance. Examples for this would be "nice" or "intelligent." The problems can arise because different people may apply different criteria to describe someone as nice or intelligent. They also notice an important feature here, which is that two or more criteria have to be fulfilled, instead of just a single criterion, before the word becomes appropriate. It is not always immediately apparent that different people give different meanings to the same word, leading to misunderstandings that may be difficult to clarify. If one person thinks that an individual is nice because he is honest, personal and warm, whereas another likes him for being honest, helpful, and friendly, a dispute can easily arise about whether that individual is nice or not, without there being any actual disagreement about the traits attributed to him.

\section{Dissociation}

Broadly speaking, the word dissociation means separation. However, Perelman and Olbrechts-Tyteca (1969) introduced the term to refer to a technique used in argumentation. In their book The New Rhetoric: A Treatise on Argumentation, they make a distinction between two types of argumentation schemes - a group of schemes that rely on association and a group of schemes that rely on dissociation. As they point out, in association, the speaker connects two distinct elements, which enables the audience to derive their own judgement about one of the elements from a judgment about the other one. Van Rees $(2009$, p. 3) gives an example of deriving your own judgement of an action by assessing the consequences that the action might have. On the other hand, in dissociation, something that is believed to be a conceptual whole or unity by the audience is split up by the speaker into distinct elements. The example given by them shows just what is meant by this definition - 
the single notion of "law" can be split up by dissociation into two distinct notions, the letter of the law and the spirit of the law, as they have noticed. The dissociation of this particular notion enables the argument in favor of one, or the other, depending on which one of the two is regarded to have a predominant force.

The authors draw attention that dissociation is not the same as breaking an association because the elements connected in association were considered to be separate units. By breaking their association, it is just shown that these separate units have been connected incorrectly. However, in dissociation, a unity that was until then considered to be "an indissoluble whole is broken." A single notion that was considered to be a conceptual unity and that was referred to by a single term is split up into two new notions, which are referred to by two different terms. Dissociation, therefore, always involves a more or less fundamental restructuring of our conception of reality. The process of dissociation, in the end, results in having two distinct notions which are indicated by two terms, as Perelman and OlbrechtsTyteca named them, "term I" and "term II."

\section{Tabloids versus broadsheets}

The differences between the two formats are significant, Preston (2004, pp. 50-5) notes. Broadsheet papers rely on investigative approaches that emphasize detailed coverage and a rational tone in articles and editorials. Some of the visual features of broadsheet articles are smaller headlines, fewer pictures and longer texts. On the other hand, tabloid content tends to expose misconduct and explore conservative topics. In terms of article composition, Rowe (2011, p. 455) notes that tabloid articles on average emphasize headlines and images. Turner (1999, p. 60) acknowledges that the tabloid press sacrifices information for entertainment, accuracy for sensation and uses tactics that draw the audiences' attention. Richardson and Stanyer (2011, p. 991) believe that tabloids and broadsheets appeal to different audiences with limited overlap. Articles about salient issues, rather than human interest and lifestyle themes, will most likely appeal to the readership of British broadsheets. Likewise, commentaries concentrated on lifestyle issues such as sport, celebrity and gardening receive comparatively fewer comments in comparison with commentaries concentrated on domestic politics and party policy. On the other hand, most comments made in British tabloids are concentrated on religion, with the majority of online posts focusing on lifestyle themes such as sport, celebrities and gardening. Relying on Rowe (2011, p. 460) and Andersen's (1997) characterizations, broadsheet newspapers are those that emphasize reliable news coverage, fastchecking and research based on a timeline in which the story unfolds. In addition to this, broadsheets offer political coverage with many details, which appeals more to a readership that is interested in politics. On the other hand, tabloid newspapers present less detailed articles often directed by marketing departments and heavily influenced by demographic appeal and audience share, which on average appeals more to younger and less educated population. Moreover, Rowe (2011, p. 460) notes 
that while broadsheet journalists devote an extensive amount of time refining codes of ethics, tabloid journalists put less emphasis on how the product is collected, how it is presented and why it is presented in such a way.

\section{Methodological framework}

The analysis is based on the Language Use Rule, which proposes that interlocutors may not use formulations that are unclear or ambiguous. The examples for the analysis were taken from the online British and American broadsheet and tabloid newspapers. Five newspapers come from the United Kingdom, three of which are broadsheet and two tabloid newspapers. Three newspapers come from the United States of America, of which one is a broadsheet and two are tabloid newspapers. The articles deal with two political issues and they were posted in 2018, 2019 and 2020. In total, 14 articles were analyzed - seven from broadsheet and seven from tabloid newspapers. The words and phrases that were identified were assumed to be problematic from the aspects of vagueness and dissociation and the context in which they were used. Two topics were taken into consideration because of their temporal proximity, relevance and applicability. The topics are the migrant crisis that has been happening since 2014 and the 2019 Hong Kong protests. The examples for the analysis were taken from the following newspapers:

Table 1 Overview of the newspapers used as sources of the identified examples

\begin{tabular}{ccc}
\hline Name & \multicolumn{1}{c}{ Country } & Format \\
\hline The Guardian & The United Kingdom & Broadsheet \\
\hline Reuters & The United Kingdom & Broadsheet \\
\hline iNews & The United Kingdom & Broadsheet \\
\hline The Sun & The United Kingdom & Tabloid \\
\hline Express & The United Kingdom & Tabloid \\
\hline Politico & The United States of America & Broadsheet \\
\hline The Blaze & The United States of America & Tabloid \\
\hline CNN & The United States of America & Tabloid
\end{tabular}

\section{Research results and discussion}

The examples identified are presented in Table 2 and Table 3 . More precisely, examples of vagueness and dissociation that were identified in both newspaper formats on the topic of the migrant crisis are listed in Table 2. In Table 3, examples of vagueness and dissociation identified in both newspaper formats on the topic of 2019 Hong Kong protests are presented. 
Table 2 Examples of vagueness and dissociation identified in broadsheets and tabloids on the topic of the migrant crisis

\begin{tabular}{|c|c|c|}
\hline & Broadsheets & Tabloids \\
\hline Vagueness & $\begin{array}{l}\text { - Deconstruction of immigration policy } \\
\text { - Detained in underground cells } \\
\text { - Elsewhere } \\
\text { - "High risk" countries } \\
\text { - "High risk" nationalities } \\
\text { - "Hostile environment" } \\
\text { - Need another step } \\
\text { - "Risk" } \\
\text { - Somewhere else } \\
\text { - Thwarted } \\
\text { - } \quad \text { The undesirable" nations } \\
\text { - Undesirable countries }\end{array}$ & $\begin{array}{ll}- & \text { Legally } \\
\text { - } & \text { Criminal aliens } \\
\text { - } & \text { Immigration violators }\end{array}$ \\
\hline Dissociation & $\begin{array}{ll}\text { - } & \text { Asylum seekers } \\
\text { - } & \text { Asylum-seeker status } \\
\text { - } & \text { Economic immigrants } \\
\text { - } & \text { Refugees } \\
\text { - } & \text { Migrants }\end{array}$ & $\begin{array}{ll}\text { - } & \text { Asylum seekers who do not } \\
\text { - } & \text { depart } \\
\text { - } & \text { Genuiled asylum-seeker } \\
\text { - } & \text { Illegal immigrants } \\
\text { - } & \text { Illegal population } \\
\text { - } & \text { Probable overstayers } \\
\text { - } & \text { Visa-overstayers } \\
\text { - } & \text { Unauthorised immigrants } \\
\text { - } & \text { Unauthorised migrants }\end{array}$ \\
\hline
\end{tabular}

Table 3 Examples of vagueness and dissociation identified in broadsheets and tabloids on the topic of Hong Kong protests

\begin{tabular}{|c|c|c|}
\hline & Broadsheets & Tabloids \\
\hline Vagueness & $\begin{array}{ll}\text { - } & \text { Democracy } \\
\text { - } & \text { Democratic tsunami } \\
\text { - } & \text { Increasing erosion of freedoms } \\
& \text { Peaceful, safe and orderly } \\
\text { - } & \text { situation } \\
\text { - } & \text { Sometimes violent protests } \\
\text { - } & \text { Crimingly resourced opposition } \\
\text { - } & \text { Demonstrivity } \\
\text { - } & \text { Issue of human rights and } \\
& \text { democracy } \\
\text { - } & \text { Suppressing human rights or } \\
& \text { democracy }\end{array}$ & $\begin{array}{ll}\text { - } & \text { Rabble-rousers } \\
\text { - } & \text { Some senior US politicians and } \\
\text { diplomatic officials } \\
\text { - Wanton, fact-distorting and } \\
\text { - inflammatory } \\
\text { 'Human rights', 'democracy' and } \\
\text { 'beautiful sights' } \\
\text { - Pretentious cover for Western } \\
\text { interference }\end{array}$ \\
\hline
\end{tabular}

The first hypothesis of this paper claimed that the choice of words and phrases in the broadsheet newspapers would be more precise than in the tabloid newspapers. However, the results obtained were different from what had originally been claimed. Looking at the 44 examples identified, we can notice that 27 examples of vagueness and dissociation were identified in the broadsheets, which is 10 more than the 
number of examples identified in the tabloids. Correspondingly, the broadsheets contained more examples of vagueness than the tabloids. Interestingly, the examples of dissociation were predominant in the tabloids when compared to the examples of vagueness in the tabloids and compared to the examples of dissociation in the broadsheets.

In total, 44 examples were identified:

1) There are 27 examples from broadsheets (of which 22 were examples of vagueness and 5 examples of dissociation) and 17 examples from tabloids (of which 8 were examples of vagueness and 9 examples of dissociation);

2) There are 30 examples of vagueness and 14 examples of dissociation.

Table 4 Number of examples identified

\begin{tabular}{ccc|c}
\hline & Broadsheets & Tabloids & Total \\
\hline Vagueness & 22 & 8 & 30 \\
\hline Dissociation & 5 & 9 & 14 \\
\hline Total & 27 & 17 & 44
\end{tabular}

The results were more unexpected if we focus only on the topic of the migrant crisis. When describing people who fled their home countries, a concurrence in the choice of words with dissociative meanings was identified - the notions of asylum seekers, refugees, migrants and immigrants were present in both formats. Similarly, both broadsheet and tabloid newspapers repeatedly used adjectives to pre-modify the aforementioned nouns and nouns such as, for example, countries, population, nations, nationalities and other. Taking into consideration that these adjectives could, to someone's judgement, seem uncommon and confusing, they were identified as examples for the analysis. In the broadsheets, the words countries and nations were pre-modified with the adjective undesirable, the words countries and nationalities with high risk, whereas in the tabloids, the words migrants and immigrants were premodified with unauthorized, and the words immigrants and population with illegal. One interesting example was found in a tabloid - the adjective genuine was used to modify the noun refugees. The adjective itself is usually used in positive contexts, however, what it indicated here was that there were refugees that were considered genuine (real, legitimate) as they possessed all the essential characteristics of a refugee, whereas the others, who were not denoted as genuine, did not.

The examples identified for the topic of Hong Kong protests were more unified - no example was labeled as an example of dissociation. They were vague in the sense that it could not be claimed with certainty to what they were alluding to or whether they were used to obscure the real situation. Namely, the protests were described conflictingly, which could easily cause perplexity. For example, the protests were labeled as democratic and safe, but also as sometimes violent and riotous.

The second hypothesis stated that the choice of words and phrases used when reporting the news about the same event and topic would differ between the formats. More precisely, it was expected that the choice of words and phrases that the tabloids 
made would be driven by the wish to draw the readers' attention, regardless of their specificity and definiteness. This hypothesis turned out to be correct.

Regarding the words and phrases identified in the broadsheets, the choice seemed to be less dramatic and catchy. The only phrases that could be described as exaggerated would be high risk countries, high risk nationalities, hostile environment, undesirable nations and undesirable countries. All the examples, except the last one, were put under the quotation marks. The importance of this will be discussed later. Another thing to notice is the fact that some phrases appeared both in the broadsheets and tabloids, with a slight important difference. Namely, the noun asylum seeker appeared in the unmodified form in the broadsheets. However, the tabloids used the noun phrase in an environment that added to the meaning (asylum seekers who do not depart, failed asylum-seekers) and could have been used to draw the attention of readers. The nouns immigrant and migrant were used in a similar manner. In the broadsheets, they had a natural tone, whereas, the tabloids added the adjectives (illegal, unauthorized) that gave it more of a negative, eye-catching effect.

Therefore, it can be concluded that the words and phrases in the tabloids seemed to be more direct, straightforward and blunt. The best examples for this would be criminal aliens and immigration violators for the topic of the migrant crisis and rabble-rousers and wanton, fact-distorting and inflammatory for the topic of Hong Kong protests.

The third hypothesis claimed that by using particular words and phrases, the newspapers could show their attitude towards the political issue in question and that, by doing this, they could try and affect the readers' viewpoint. Regarding this, there was one interesting detail. It was noticed that the analyzed words and phrases were put under the quotation marks in the broadsheets more frequently than they were in the tabloids. This may hint that the broadsheets were reporting someone's exact words, that they did not agree with what was implied by choosing that particular word or phrase, or that the choice of words was rather uncommon. When reporting someone's speech, particular words or phrases were put under the quotation marks, e.g. "[...] Foxglove said the Home Office refused to publish its list of what the campaign group labelled "the undesirable" nations [...]". Interestingly, even when quoting someone's exact sentences, the particular words or phrases were additionally marked with quotation marks, e.g. "[...] it is likely that information about 'high risk' nationalities will be biased by definition [...]". Looking at these examples, one implication may be that the use of quotation marks suggests that the broadsheets refrained from showing their attitude towards the problem. Having put certain words and phrases under quotation marks, the broadsheets only copied what someone else had said and avoided taking the blame if the choice of words was not appropriate. Another implication may be that they did not agree with the choice of words and wanted to signal that to the readers. This was rarely the case with the tabloids. All but one of the examples were used without the quotation marks which may imply, if we compare it to the previous interpretation, that the tabloids agreed with the choice of words and phrases.

The presumed difference between the two formats was more difficult to notice in the examples that were not put under the quotation marks. However, if we connect the previous hypothesis where it was claimed that the choice of words in the tabloids 
was more direct, the interpretation given in the previous passage can be solidified. Namely, having picked the words that were extreme and prominent, the tabloids tried to compose articles that were eye-catching and discernible. Hence, it can be concluded that the analyzed words in the tabloids may have been selected to draw the readers' attention and as a consequence, affect their attitude towards the issue. Therefore, influencing someone's attitude and stance towards a political problem could be established as the main priority of the tabloids.

The reason why the hypotheses which dealt with the precision regarding possible choices of words and phrases were inclined towards the broadsheet newspapers was the belief that the differences in quality (as discussed by the authors mentioned in the theoretical background), would result in clear differences in vocabulary. It was assumed that the more effort the broadsheet newspapers put into their articles (from the examination of topics to the composition and the writing of articles itself), the more it would reflect in how well the articles were written.

To sum up, the first hypothesis proved to be wrong. The choice of words and phrases was not much different when it came to the clarity and precision. Examples of both vagueness and dissociation were found both in the broadsheets and tabloids. In fact, more examples were found in the broadsheets. Furthermore, both formats used modified nouns, even if the combination of words may have been uncommon or the source of confusion in the readers. The second hypothesis turned out to be correct. The choice of words and phrases in the broadsheet newspapers was not as catchy as it was the case in the tabloids. Therefore, the tabloids try to draw readers' attention by choosing to use the words that are noticeable, unusual and vague. Similar words appeared in the broadsheets as well. Still, there was one difference, which brings us to the third hypothesis. Namely, some words and phrases were put under the quotation marks in the broadsheets, which was rarely the case with the tabloids. Having added the quotation marks, the broadsheet newspapers might have had the intention to refrain from using their own words or to indicate that those combinations might not have been the most adequate referring expressions.

\section{Conclusion}

By analyzing the broadsheet and tabloid articles written on two political topics, this paper has shown the difference between the formats when it comes to the use of the words and phrases that can be identified as the examples of vagueness and dissociation. The articles analyzed were the online versions of the eight selected British and American broadsheet and tabloid newspapers which concentrated on the topic of the migrant crisis and the Hong Kong protests. The theoretical framework and the context were taken into consideration when identifying and analyzing the examples.

Findings from this thesis show that the differences between the formats resulted in the differences in the use of vocabulary. One reason for this may be that due to the fact that the broadsheet newspapers should ideally focus on presenting 
news as factual and accurate, there is no space for using vagueness and dissociation as attention-grabbers. Tabloids, on the other hand, used eye-catching language to attract readers' attention as this could be one of the methods to engage readers and change their outlook on the issue. These results agree with the discrepancy between the formats' audiences. The broadsheets target people who want to get updated about serious subject matters, such as, for example, politics. Yet, tabloids attract casual readers with different interests, mainly sports, pop culture, rumors, etc.

The most noticeable limitation of the research was the number of articles analyzed. However, regardless of this limitation, the results led to the conclusions that may be useful for further research. Still, it would be of significant importance if similar research would use a larger sample of articles to analyze. Statistically examining the examples would give us a better insight into the prevalence of vagueness and dissociation. Also, the theoretical framework used for this thesis was concerned with the Language Use Rule, strategic maneuvering and pragmadialectics. Aside from this theoretical framework, the problem that this thesis tackled could be examined within different theoretical frameworks and in different analytical manners. For example, the research could involve subjects who read the articles and decide whether certain words and phrases lack clarity and precision. That way, the decision whether certain meanings of words were vague or dissociative would not be made by the researcher only, but instead would illustrate what readers detected as suitable examples.

\section{References}

Andersen, R. (1997). Do Newspapers Enlighten Preferences? Personal Ideology, Party Choice and the Electoral Cycle: The United Kingdom, 1992-1997. Canadian Journal of Political Science, 30(03), 601-619. DOI: 10.1017/S0008423903778780

Fenstad, J. E. (2011). Partiality. (J. Van Benthem, \& A. Ter Meulen, Eds.) Handbook of Logic and Language, 691-708. DOI: 10.1016/B978-0-444-53726-3.00014-1

Perelman, C., \& Olbrechts-Tyteca, L. (1969). The new rhetoric: A Treatise on Argumentation (Vol. 13). Notre Dame/London: University of Notre Dame Press.

Preston, P. (2004). Tabloids: Only the Beginning. British Journalism Review, 15(1), 50-55.

Richardson, J. E., \& Stanyer, J. (2011). Reader opinion in the digital age: Tabloid and broadsheet newspaper websites and the exercise of political voice. Journalism, 12(8), 983-1003. DOI: $10.1177 / 1464884911415974$

Rowe, D. (2011). Obituary for the Newspaper? Tracking the Tabloid. Journalism, 12(4), 449-466. DOI: $10.1177 / 1464884910388232$

Turner, G. (1999). Tabloidization, journalism and the possibility of critique. International Journal of Cultural Studies, 59-76. DOI: 10.1177/136787799900200104

van Eemeren, F. H., \& Grootendorst, R. (2004). A Systematic Theory of Argumentation: The pragma-dialectical approach. Cambridge: Cambridge University Press.

van Eemeren, F. H., \& Grootendorst, R. (2016). Argumentation, Communication, and 
Fallacies: A Pragma-Dialectical Perspective. New York: Routledge.

van Rees, A. (2009). Dissociation in Argumentative Discussion: A Pragma-Dialectical Perspective. Amsterdam: Springer Netherlands.

van Eemeren, F. H. (2010). Strategic Maneuvering in Argumentative Discourse: Extending the pragma-dialectical theory of argumentation (Vol. 2). Amsterdam/Philadelphia: John Benjamins Publishing Company.

van Eemeren, F. H. (2018). Argumentation Theory: A Pragma-Dialectical Perspective (Vol. 33). Cham: Springer International Publishing.

Williamson, T. (2001). Vagueness, Indeterminacy and Social Meaning. In C. Grant, \& D. McLaughlin (Eds.), Language - Meaning - Social Construction: Interdisciplinary Studies (Vol. 16, pp. 61-76).Amsterdam: Rodopi. DOI: 10.1163/9789004333963_005

\section{NEJASNOĆA I DISOCIJACIJA U DISKURSU POLITIČKIH VESTI NA ENGLESKOM JEZIKU}

Apstrakt. Glavni cilj rada je da istakne značaj problema nejasnoće i disocijacije u interpretaciji diskursa. Diskurs koji je uzet u obzir u ovom radu je diskurs političkih vesti na engleskom jeziku. Ovaj diskurs je lako dostupan svim čitaocima i bavi se važnim političkim pitanjima, što nameće potrebu da korišćene reči i sintagme budu nepristrasne i precizne. U suprotnom, čitaoci mogu pogrešno protumačiti diskurs $i$ stvoriti pogrešan utisak o političkom problemu. U ovom radu, novinski članci su uzeti kao primer političkog diskursa. Svi članci koji su u ovom radu analizirani su objavljeni u onlajn verzijama britanske $i$ američke informativno-analitičke štampe i tabloidima i bavili su se dvema temama - migrantska kriza i protesti u Hong Kongu 2019. godine. Uzimajući u obzir politički kontekst $i$ teoretski okvir koji je relevantan za ovaj rad, identifikovana su 44 primera nejasnoće i disocijacije koji su pronađeni u 14 novinskih članaka.

Ključne reči: disocijacija, nejasnoća, informativno-analitička štampa, tabloidi,politički diskurs, pragma-dijalektika 